\title{
Primary Teachers Knowledge of Quadrilaterals
}

\author{
Yasin Gokbulut ${ }^{1} \&$ Mustafa Sen ${ }^{2}$ \\ ${ }^{1}$ Primart Education, Tokat Gaziosmanpasa University, Tokat, Turkey \\ ${ }^{2}$ Ministry of Education, Tokat, Turkey \\ Correspondence: Yasin Gokbulut, Primary Education Tokat Gaziosmanpasa University, A 304 Tasliciftlik Tokat, \\ Turkey. Tel: 050-5711-9927. E-mail: yasingkbulut@yahoo.com
}

Received: January 11, 2019

Accepted: January 25, 2019 Online Published: February 11, 2019

doi:10.5539/hes.v9n2p1

\author{
URL: https://doi.org/10.5539/hes.v9n2p1
}

\begin{abstract}
This paper aims to reveal primary teachers knowledge of the quadrilaterals about the concept of quadrilaterals by examining the definitions of the quadrilaterals. A total of four primary teachers, 1 female and 3 male teachers, participated in the study which determined by maximum diversity sampling. The data collection tool consisted of four open-ended questionnaires, which were not based on mathematical procedural knowledge of the teachers and aims to reveal the subject matter knowledge of quadrilaterals. The first question is about the definition of the quadrilaterals (square, rectangle, trapezoid, parallelogram, rhombus and deltoid), the second question is the determination of the characteristics of the quadrilaterals, the 3rd question is the comparison of the characteristics of the quadrilaterals and the 4th question is about related to the nomenclature of the quadrilaterals. The data were analyzed by using descriptive analysis method (Zazkis \& Leikin, 2008). As a result of analyzes, it was seen that the subject area information of the participants was insufficient. In order to be successful in the teaching of geometry, the in-service training activities should be organized in order to eliminate the deficiencies in the subject matter knowledge and the necessity of reviewing the mathematics courses they took at the university, which can be corrected first, in the context of the content.
\end{abstract}

Keywords: quadrilaterals, primary teachers, definition

\section{Introduction}

Geometry is an important branch in which mathematics, shapes and space are studied, a theoretical system where definitions play a critical role. Depending on the natural complexity of the identification process, it is unreasonable to expect students to have immediate recognition on their own, and this can be done through their personal efforts and identification examples that they can use as models. Definitions and ways of presenting the students shape the relationship between concept image and concept definition (Zazkis \& Leikin, 2008). In the minds of learners, the concept image belonging to the concept is formed firstly, after the concept image has been formed, the proper definition takes place in the mind of the learner. Visual presentation, impression and experiences of the cognition make the first concept image (Tsamir, Tirosh and Levenson., 2008).

Quadrilaterals are a common concept for people in daily life, and although they do not take place as subjects, it is an important element in geometry when it is taught from the first grade in the context of quadrilateral family. The concept of quadrilaterals is a concept that has a set of rich states that can be presented, but also misconceptions. The misconception spreads rapidly from person to person such as a virus. In this dissemination, those who teach a concept to others without knowing it can play an active role. In this context, it is important to investigate the definitions of primary teachers to prevent misconceptions.

This study is a part of the study, which is the subject of knowledge of pedagogical content knowledge of quadrilaterals (square, rectangle, ..), knowledge of students' comprehension knowledge, program knowledge and strategy method technical knowledge. The subject matter knowledge is the amount and organization of the information in the minds of the teachers (Shulman, 1986). In this study, definition was considered as the main component of the subject matter knowledge of primary teachers.

This study, in which teachers' identification information about quadrilaterals is examined, is important because it is a study that is concerned with increasing the quality and quality of teachers in the field of education, and it is important because they can contribute to the elimination of the misconceptions about the concept of quadrilateral and in the preparation of the mathematics lesson in line with the findings. 


\subsection{Definition and Mathematics}

Describing the definition is to reveal one by one with several characteristic features of a known object, (Freudenthal, 1973). When Van Hiele is considered in terms of defining the levels of geometric thinking, it can be said that when the level increases, the definition also changes, starting with the uneven definition at the level of 0 and reaching a maximum level at which the proper definition of the concepts at 3 levels is reached (van Hiele, 1986). The position of identification in van Hiele levels is depicted by Jaime and Gutierrez at each level. At 0 (Visual) level, students consider physical objects with features that are not general or mathematical. For example, they consider only features such as round for the circle. Therefore, they cannot use and explain mathematical definitions. Sometimes the concept's name is the definition itself; for example, children often say, square frame when asked what the square is. At the 1 (Analytical) level, students strive for mathematical properties, but they have problems with some logical principles, such as "at least" etc when they use the definition or explain it. When explaining a definition, students may sometimes neglect the features that are exactly the features they use. At other times, it creates more list of features than needed. For example, some students describe a rectangle as a parallel with two pairs of edges, on which these two sides are longer than the other one (right angle reference is omitted). Other students can define a rectangle as two parallel pairs of parallels, two sides of which are longer than the other, four perpendicular angles, and two parallel sides with a parallel edge (extra features are included). At the level of "2" (Informal Inference Due to Experience) They can interpret and explain mathematical definitions, are conscious of the existence of a necessary and sufficient set of properties, and they know that adding more features to recognition cannot result in better definition. Therefore, while providing a definition, students try not to be unnecessary. At the level of 3 (Inference) and 4 (Mathematical certainty), the process of reasoning at level 2 continues with the ability to better understand the definitions and to prove different equal definitions of the same concept. A sample of equivalence classes can be established by exemplifying the logical relations between the states of comprehension (Jaime \& Gutiérrez, 1994).

Studies have shown that students have difficulty in interpreting and using the new definitions appropriately (Dahlberg \& Housman, 1997; Edwards \& Ward, 2004; Zaslavsky \& Shir, 2005; Zazkis \& Leikin, 2008; Türnüklü, 2014; Alcock \& Simpson, 2017; Özyıldırım-Gümüş \& Şahiner, 2017; Unlu \& Horzum, 2018). Knowing only the definition of a concept does not guarantee an understanding of the concept. For example, the student may define or recite the definition of the standard parallelogram as a rectangular quadrangle with parallel sides, but the students may still use the rectangular, square and rhombus, as a parallelogram unless the concept images of a parallelogram are allowed to be equal in all angles or edges. (De Villiers, 1998).

\section{Method}

\subsection{Participants}

In this study, a case study which is one of the patterns of qualitative research methodology is used. A case study is a method that allows an in-depth examination of an event, a limited number of samples and boundaries on a given subject (Mcmillian \& Schumacher, 2010). The study group consisted of four primary teachers, three male and one female, working in Artova district of Tokat province in 2016-2017 academic year. The study group of the study was determined by the maximum diversity of the selected primary teachers by taking into consideration the different levels of the classes. Using the maximum diversity sampling, the situation of teachers who read each grade level was tried to be illustrated. The names of the teachers chosen by considering work ethics and ethics were kept confidential and nicknames (T1, T2, T3 and T4) were used. Class levels of primary teachers in the study group of the study are given in Table 1.

Table 1. Class levels of participant teachers

\begin{tabular}{ll}
\hline Teachers & Grades \\
\hline $\mathrm{T} 1$ & 1 \\
$\mathrm{~T} 2$ & 2 \\
$\mathrm{~T} 3$ & 3 \\
$\mathrm{~T} 4$ & 4 \\
\hline
\end{tabular}

\subsection{Data Collection and Analysis}

As a means of collecting data, the interview form, which was developed by the researchers, was used to reveal the concept of quadrilaterals, consisting of four open-ended questions in the type of expressive information that they could answer without requiring any transaction. The first question is the definition of the quadrilaterals (square, rectangle, trapezoid, parallelogram, rhombus and deltoid), the second question is the determination of 
the characteristics of the quadrilaterals, the 3rd question is the comparison of the characteristics of the quadrilaterals and the 4th question is related to the nomenclature of the quadrilaterals. While this data collection tool is being created, 1-4 mathematics program, 1-4 textbooks, 1-4 teacher's guidebooks and studies on pedagogical content knowledge are examined and similar kinds of questions have been prepared for quadrilaterals. Experiences of experienced primary teachers and an academician with pedagogical content knowledge were obtained by taking the necessary corrections.

The interview form was started to be applied to the participants in the second term of 2016-2017 academic year. The application lasted approximately 1 hour and 15 minutes for each participant. In order for the participants to respond to the interview questions willingly and comfortably, the teachers were interviewed at a place they wanted and their preference effects were discussed at a time.

Before the interview, the participants were informed that their private information, including their names, would not be used in any way within the framework of the ethical rules in order to respond to the questions in a sincere manner. The participants were informed about the study and the interview. In order to prevent participant teachers from responding to each other or from another person in the environment, face-to-face interview technique was applied. Interviews were recorded with the consent of the participants and then recorded.

Ball (1988) proposes probe questions to validate the answers given and reveal the underlying causes of thoughts. After the answers of the participants, it was tried to learn the thoughts and opinions of the answer which was mostly asked by asking why.

The data were analyzed by descriptive analysis method. By using the responses of the participants and the literature, the definitions of quadrilaterals were examined by the criteria of accessibility and accuracy (Zazkis \& Leikin, 2008), and the findings obtained by coding were interpreted according to the aims. The content of these criteria is briefly as follows:

Accessibility criterion: Whether the participants respond to the questions posed, make an effort to give the right answer, and whether they can make more than one alternative definition when describing the quadrilaterals are considered. The participants answered the question with hesitance (hesitating about waiting and accuracy) while the answer was given to the question, the answer given to the question without hesitation (given without giving any thought) was easily given and the answer was evaluated as no answer if no answer was given.

Accuracy criterion: The answers of the participants to the definition questions and the definitions they made were examined by classifying them as exact answer and incomplete response in terms of accuracy. Responses including answers to questions and definitions containing all critical features were considered to be incomplete, or those that did not contain or part of the answers were considered to be incomplete. The definitions of the quadrilaterals which are taken as basis for the analysis of the research consist of the book titled as Geometry written by Gazi Mustafa Kemal Atatürk (TDK, 2009) and the definitions in the Glossary of Mathematics Terms (Hacioğlu, et al., 2009). According to these two sources, the square is "Smooth rectangle with all edges and angles equal to each other", rectangle is "Rectangular with parallel, vertical and parallel sides", trapezoid is "Quadrilateral which have at least two sides are parallel", parallelogram is "Quadrilateral which have parallel and equal opposite sides", rhombus is "A quadrilateral which have four equal sides", deltoid is "Quadrilateral formed by two isosceles triangles which bases overlapping". In the light of these definitions, the critical properties of the quadrilaterals are determined as in Table 2.

Table 2. Critical properties of quadrilaterals

\begin{tabular}{|c|c|c|c|c|c|}
\hline Square & Rectangle & Trapezoid & Parallelogram & Rhombus & Deltoid \\
\hline $\begin{array}{l}\text { The four edges are equal } \\
\text { to each other and the } \\
\text { four angles are } 90 \\
\text { degrees }\end{array}$ & $\begin{array}{l}\text { The opposite sides are } \\
\text { equal and the four } \\
\text { angles are } 90 \text { degrees }\end{array}$ & $\begin{array}{l}\text { At least two } \\
\text { sides being } \\
\text { parallel }\end{array}$ & $\begin{array}{l}\text { Opposite sides } \\
\text { being parallel }\end{array}$ & $\begin{array}{l}\text { Four sides } \\
\text { of equal } \\
\text { length }\end{array}$ & $\begin{array}{l}\text { Adjacent edge are equal } \\
\text { and diagonals are } \\
\text { perpendicular }\end{array}$ \\
\hline
\end{tabular}

\subsection{Validity}

Building validity is the correct operational measurements for the studied concepts (Yin, 2003). The construct validity of this study tried to provide by, a careful literature search when creating a data collection tool, the accuracy of the data collection tool, the first hand control by the researchers who are mathematicians, the studies on the formation and analysis of the data collection tool (such as coding and theme of data), it is tried to obtain the structure validity by having the opinion of the second researcher who gives undergraduate and graduate courses in the field of higher education in this field, which has mastery of qualitative research methodology and 
supports the collected data. In this study, in addition to the definitions of the participants and the correctness of the examples they gave, how the given answer is given is analyzed by the criteria used in the analysis. This is another factor that increases the validity of the research.

\section{Results}

In this section, the findings are presented and interpreted one by one in the light of the open-ended questions in the data collection tool.

\subsection{Different Definitions of Quadrilaterals}

Under this heading, the definitions of the quadrilaterals that the participants could do differently were examined. The participants were asked to make a second definition other than the first definition after they were asked to make a definition of a quadrilateral. Table 3 shows the first and second square definitions of the participants.

Table 3. Square expansions of participants

\begin{tabular}{|c|c|c|}
\hline Participants & First definition & Second definition \\
\hline $\mathrm{T} 1$ & $\begin{array}{l}\text { It is a geometric shape that has equal edges, parallel edges and } \\
\text { parallel sides. }\end{array}$ & $\begin{array}{l}4 \text { corners with } 4 \text { sides of all edges of the geometric shape is } \\
\text { equal to each other }\end{array}$ \\
\hline $\mathrm{T} 2$ & $\begin{array}{l}\text { Geometric shape with } 4 \text { corners, } 4 \text { sides and equal edge } \\
\text { lengths }\end{array}$ & All rectangles are equal and the angles are vertical \\
\hline $\mathrm{T} 3$ & All sides are equal to the shape called square & Edge lengths and angles are equal \\
\hline $\mathrm{T} 4$ & $\begin{array}{l}\text { The four sides are equal, all angles are equal and the } 90^{\circ} \text { is } \\
\text { called the quadrilateral }\end{array}$ & All edges with four sides are called squares. \\
\hline
\end{tabular}

When the answers were examined in terms of accessibility, it was seen that the first and second definitions of all participants were easy answers. When the answers are examined in terms of accuracy, for the first definition, the exact definition of $\mathrm{T} 1$ and $\mathrm{T} 4$ and the perpendicularity of the angles in the definitions of $\mathrm{T} 2$ and $\mathrm{T} 3$ are considered as incomplete definitions because the critical feature is not accommodated. For the second definition, the exact definition of T2 and T3 and the vertical orientation of T1 and T4 are considered as incomplete definition since they do not contain the critical feature. Table 4 shows the first and second rectangular definitions of the participants.

Table 4. Rectangular definitions of participants

\begin{tabular}{|c|c|c|}
\hline Participants & First definition & Second definition \\
\hline $\mathrm{T} 1$ & $\begin{array}{l}\text { It is a geometric shape that has two long two short sides and its } \\
\text { opposite sides are parallel to each other. }\end{array}$ & $\begin{array}{l}\text { Rectangular is a geometric shape with } 4 \text { corners with } 4 \\
\text { sides equal to the length of the opposite sides }\end{array}$ \\
\hline $\mathrm{T} 2$ & $\begin{array}{l}\text { They are geometric shapes with equal edge lengths equal and } \\
\text { angles }\end{array}$ & We can say that it is stretched form of square \\
\hline $\mathrm{T} 3$ & $\begin{array}{l}\text { Geometric shapes are called rectangles with opposite short and } \\
\text { opposite long sides equal to each other and } 90^{\circ} \text { in all angles }\end{array}$ & Short and long sides with short and long edges are equal \\
\hline $\mathrm{T} 4$ & $\begin{array}{l}\text { Rectangles with four sides equal to each other, four angles with four } \\
\text { angles and all angles of } 90^{\circ}\end{array}$ & $\begin{array}{l}\text { It is called quadrangles with equal and short edges with } \\
\text { four sides. }\end{array}$ \\
\hline
\end{tabular}

When the answers were examined in terms of accessibility, the first and second definitions of the participants all other definitions, except the second definition of T2, are an easy answer. In the second response of T2, it was taken into consideration as a difficult answer because it made a definition by coming back again. When the answers were examined in terms of accuracy, it was seen that all participants had a exact definition for the first definition. For the second definition, the definition of T1, T3 and T4, which are not perpendicular to the angle of the angles, are incomplete, and the definition of $\mathrm{T} 2$, which is not exactly defined, can be considered as incomplete. Table 5 shows the first and second trapezoidal definitions of the participants. 
Table 5. Trapezoidal definitions of the participants

\begin{tabular}{|c|c|c|}
\hline Participants & First definition & Second definition \\
\hline $\mathrm{T} 1$ & $\begin{array}{l}\text { The other two sides of the opposite edge parallel are non-parallel geometric } \\
\text { shapes. }\end{array}$ & $\begin{array}{l}\text { I can't make the second definition, I felt } \\
\text { very inadequate }\end{array}$ \\
\hline $\mathrm{T} 2$ & $\begin{array}{l}\text { Half of the upper edge and lower edge length are the geometric shape that forms } \\
\text { the middle edge }\end{array}$ & $\begin{array}{l}\text { I couldn't make, I make the first } \\
\text { definition difficult }\end{array}$ \\
\hline $\mathrm{T} 3$ & The two narrow and two wide angles are different from each other. & I can't make a second definition \\
\hline $\mathrm{T} 4$ & $\begin{array}{l}\text { The quadrangles are independent of each other, the two narrow rectangles with } \\
\text { two wide angles are called trapezoid. }\end{array}$ & I can't make a second definition \\
\hline
\end{tabular}

When the answers were examined in terms of accessibility, the first and second definitions of T1 and T3 were taken into consideration as a hard answer because the other explanations of the first definitions of T1 and T3 were given in the case of thinking for a long time. When the answers are examined in terms of accuracy, for the first definition $\mathrm{T} 1$ made exact definition and $\mathrm{T} 2, \mathrm{~T} 3$ and $\mathrm{T} 4$ are considered as incomplete definitions because they do not contain the parallelism of at least two edges. For the second definition, all participants were unable to identify. Table 6 shows the first and second definitions of the participants for the parallelogram.

Table 6. Parallelogram definitions of participants

\begin{tabular}{lll}
\hline Participants & First definition & Second definition \\
\hline $\mathrm{T} 1$ & $\begin{array}{l}\text { Two adjacent angles whose parallel edges are parallel and not } \\
\text { perpendicular, are called rectangles with a total of } 180^{\circ} .\end{array}$ & The rectangle has a non-perpendicular shape \\
& Rectangles with parallel sides and parallel sides are equal & The rectangle has a non-perpendicular shape \\
$\mathrm{T} 2$ & $\begin{array}{l}\text { The opposite edges and opposite angles are parallel to each other and } \\
\text { are parallel to the geometric shape. }\end{array}$ & $\begin{array}{l}\text { Unlike rectangles, angles are geometric shapes that } \\
\text { are not perpendicular. }\end{array}$ \\
& Rectangles with two narrow angles and two opposite angles with each & We can call the rectangular sheared state. So the \\
T4 & ather. & angles are not perpendicular \\
& &
\end{tabular}

When the answers were examined in terms of accessibility, the answers given in the first and second definitions were considered as easy answers. When the answers are examined in terms of accuracy, it is seen that in the first and second definitions, all participants make exact definitions which contain all critical features. Table 7 shows the first and second definitions of the participants for the rhombus.

Table 7. Rectangular definitions of participants

\begin{tabular}{|c|c|c|}
\hline Participants & First definition & Second definition \\
\hline $\mathrm{T} 1$ & $\begin{array}{l}\text { It is called a rectangular rectangular intersecting triangle whose edges } \\
\text { are equal, the diagonal diagonals of which the opposite sides are parallel }\end{array}$ & The square corners are non-perpendicular \\
\hline $\mathrm{T} 2$ & They are rectangular with parallel sides and parallel sides. & $\begin{array}{l}\text { Rectangles of edge lengths and diagonal (given } \\
\text { answer }=\text { margins) are equal in length }\end{array}$ \\
\hline $\mathrm{T} 3$ & $\begin{array}{l}\text { Unlike square, edge lengths are rectangles that are not angles of equal } \\
\text { angles }\end{array}$ & No definition \\
\hline $\mathrm{T} 4$ & Edge lengths are equal to each other, square different rectangles & No definition \\
\hline
\end{tabular}

When the answers were examined in terms of accessibility, it was seen that in the first definitions T1 was confused because of confusing the concepts of bisector and diagonal and the others were easy answers. In the second definitions, it was seen that $\mathrm{T} 1$ and $\mathrm{T} 2$ were easy and $\mathrm{T} 3$ and $\mathrm{T} 4$ were difficult and could not be defined. When the answers were examined in terms of accuracy, it was seen that in first definition all participants made exact definition and in the second definition $\mathrm{T} 1$ and $\mathrm{T} 2$ made exact definition $\mathrm{T} 3$ and $\mathrm{T} 4$ could not be identified. Table 8 shows the first and second definitions of the participants for deltoid. 
Table 8. Deltoid definitions of participants

\begin{tabular}{|c|c|c|}
\hline Participants & First definition & Second definition \\
\hline $\mathrm{T} 1$ & $\begin{array}{l}\text { T1: I have difficulty in defining deltoid. } \\
\text { Researcher: You draw and you try to express in writing } \\
\text { features. } \\
\text { T1: The diagonal lines are orthogonal to the opposite sides of } \\
\text { the opposite sides. }\end{array}$ & No definition \\
\hline $\mathrm{T} 2$ & $\begin{array}{l}\text { Geometrical shapes with parallel sides and parallel edges } \\
\text { intersecting vertically }\end{array}$ & No definition \\
\hline $\mathrm{T} 3$ & $\begin{array}{l}\text { The upper edge length and the lower edge lengths are special } \\
\text { shapes }\end{array}$ & The shape formed by the joining of two isosceles triangles \\
\hline $\mathrm{T} 4$ & The lower edges of the upper edges are equal to each other. & $\begin{array}{l}\text { Rectangles formed by the combination of the bases of two } \\
\text { isosceles triangles }\end{array}$ \\
\hline
\end{tabular}

When the answers were examined in terms of accessibility, in the firs definition T1 give difficult answers, T2, T3 and T4 give easy answer. In the second definitions, it was considered that $\mathrm{T} 1$ and $\mathrm{T} 2$ was unable to define and also T3 and T4 easy given answer. When the answers were examined in terms of accuracy, it was seen that in the first definitions, only the T4 defines the exact definition and the others have incomplete definition because they mix the concepts of edge, middle, and diagonal. In the second definitions, T1 and T2 were not able to define T3 and T4 made exact.

\subsection{Determining the Properties of Rectangles}

Under this heading, participants were asked to mark the appropriate properties of the rectangles in the given table. Table 9 shows the findings of $\mathrm{T} 2$.

Table 9. Participant T2's information about quadrilateral features

\begin{tabular}{lllllll}
\hline Features & Square & Rectangle & Rhombus & Parallelogram & Trapezoid & Deltoid \\
\hline Four equal edges & $\mathrm{X}$ & & $\mathrm{X}$ & & & \\
Four equal angles & $\mathrm{X}$ & $\mathrm{X}$ & $\mathrm{X}(\mathrm{Y})$ & & & \\
Two pairs of equal reciprocal edges & $\mathrm{X}$ & $\mathrm{X}$ & $\mathrm{X}$ & $\mathrm{X}$ & $\mathrm{X}(\mathrm{Y})$ & \\
Two pairs of reciprocal angles are equal & $\mathrm{X}$ & $\mathrm{X}$ & $\mathrm{X}$ & $(\mathrm{Y})$ & $\mathrm{X}(\mathrm{Y})$ & \\
Parallel to just a double edge & & & & & $\mathrm{X}$ & \\
Equal diagonal line & $\mathrm{X}$ & $\mathrm{X}$ & $\mathrm{X}(\mathrm{Y})$ & $\mathrm{X}(\mathrm{Y})$ & & \\
Diagonal crosses at right angles & $(\mathrm{Y})$ & & $(\mathrm{Y})$ & & & $\mathrm{X}$ \\
Two pairs of neighbor edge equal & $\mathrm{X}$ & & $(\mathrm{Y})$ & & & $(\mathrm{Y})$ \\
Only one double equal angle equal & & & & & $\mathrm{X}(\mathrm{Y})$ & $(\mathrm{Y})$ \\
\hline
\end{tabular}

Answer given to $\mathrm{X}$ : $\mathrm{Y}$ represents the wrong answer.

In this question, it is desirable to determine the characteristics of the rectangles. T1, 6 errors, T2, 12 errors, T3, 3 errors and T4, 4 errors were made.

\subsection{Comparison of Properties of Quadrilaterals}

The answers given to the question were examined" Is a rectangle, square, rhombus, and trapezoidal parallelogram". The answers are listed below.

T1: Except the trapezoid, they are paralleled, but they do not belong to this group because they have a parallel pair of parallel sides. In order to be parallel edge, two pairs should be parallel to each other.

T2: Not all parallelograms

T3: Not trapezoidal parallelogram. We see that the rectangular, square, and rhombus are slightly parallel to the parallelogram.

T4: It has all the features of rectangular and square parallelogram but carries some properties of rhombus and trapezoidal parallelogram. Not a parallelogram.

When the answers were examined in terms of accessibility, it was seen that the answers of all the participants were easy answers, and when all the participants were answered in terms of accuracy, all the participants answered exact answer. 


\subsection{Nomenclature of Rectangles by Corners}

Under this title, the participants were asked to ask whether the answers of the students were wrong by a scenario in which the sides and corners of the quadrilaterals were named.

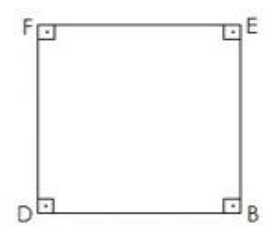

Figure 1. The Square to be Named by Corners

Let's face it, you tell the 4th graders to name the edges and corners of the rectangles. Some of your students named the figure as below;

\section{Student answer: EDFB Square \\ 2.Student answer: FEBD Square \\ 3. Student answer: FEDB Square \\ 4.Student answer: EBDF Square}

Which of the answers are correct and which ones are wrong?

The question was addressed to the participants. All participants answered" 1 and 3 are wrong, 2 and 4 are true. In terms of accessibility it was easy answer. In terms of accuracy it has seen that all participants give exact answer.

\section{Discussion}

The findings obtained from the research were in parallel with De Villiers (1998), Reed, (1972) and Tsamir et al. (2008). When participants were asked to define quadrilaterals, they had difficulty in defining the mathematical definition. When the studies related to the subject matter knowledge and pedagogical content knowledge about mathematics and geometry are examined, it is similar to Dönmez (2009), Gökbulut (2010), Gökbulut and Ubuz (2013), Aksu, (2013) and Gökkurt (2014) and Şahin (2016). It is observed that there are deficiencies in the subject matter knowledge of the teachers in which the results have been reached and the subject matter knowledge is not sufficient.

When the results of the research are considered in terms of accessibility, it is not possible for the participants to respond easily or hardly to the questions posed by them, whether the answer is appropriate or not, in other words; It can also be seen as the appropriate answer. In addition, it was seen that the difficult answers given by some participants could also be inappropriate mis-answers.

In terms of accuracy, when the quadrangular definitions of the participants are examined, it is observed that the first definitions of square and rectangle are defined in exact, but when a second definition is requested, they cannot make different definitions that is, they could not go beyond the standard (prototype) definitions they have learned. Participants make exact definitions of critical properties in the first definitions of rhombus and parallelogram, it was observed that in the second definitions of critical properties, the rhombus and the parallelogram were defined from square and rectangle. While defining the rhombus, T1 has mixed the concept of the diagonal and T2 is mixed with the concept of the equilibrium. Participants observed some misconceptions, realized T1 mistakes and corrected them, but could not realize $\mathrm{T} 2$ error. The exact definition of the critical features of the trapezoidal is made only by T1. A second definition of the trapezoidal could not be made by any participant. The exact definitions of deltoid were given by $\mathrm{T} 3$ and $\mathrm{T} 4$, and $\mathrm{T} 1$ and $\mathrm{T} 2$ were confused with the opposite side and neighboring edge concepts. The second exact definitions of the deltoid were given by $\mathrm{T} 3$ and T4. A summary of the findings related to identification in terms of accuracy is given in Table 10 . 
Table 10. Summary of the findings of the participants in terms of accuracy

\begin{tabular}{|c|c|c|c|c|c|c|c|c|}
\hline \multirow[t]{3}{*}{ Quadrilaterals } & \multicolumn{8}{|l|}{ Participants } \\
\hline & \multicolumn{2}{|l|}{$\mathrm{T} 1$} & \multicolumn{2}{|l|}{$\mathrm{T} 2$} & \multicolumn{2}{|l|}{$\mathrm{T} 3$} & \multicolumn{2}{|l|}{$\mathrm{T} 4$} \\
\hline & First & Second & First & Second & First & Second & First & Second \\
\hline Square & Complete & Incomplete & Incomplete & Complete & Incomplete & Complete & Complete & Incomplete \\
\hline Rectangle & Complete & Incomplete & Complete & Incomplete & Complete & Incomplete & Complete & Incomplete \\
\hline Rhombus & Complete & Incomplete & Complete & Incomplete & Complete & No definition & Complete & No definition \\
\hline Parallelogram & Complete & Complete & Complete & Complete & Complete & Complete & Complete & Complete \\
\hline Trapezoid & Complete & No definition & Incomplete & No definition & Incomplete & No definition & Incomplete & No definition \\
\hline Deltoid & Incomplete & No definition & Incomplete & No definition & Incomplete & Complete & Complete & Complete \\
\hline Square & Complete & Incomplete & Incomplete & Complete & Incomplete & Complete & Complete & Incomplete \\
\hline
\end{tabular}

When the Table 10 is examined, it is seen that for the first and second definitions the most comfortable definition of the quadrilateral is parallelogram and the most difficult ones are trapezoid. In the questions of determining the characteristics of the rectangles asked to support the data obtained from the quadrilateral definitions of the participants, the participants performed similar to their performance in the descriptions. T1 6, T2 12, T3 3 and T4 4 showed incorrect response in the feature table of the quadrilaterals. According to the corners of the rectangles, it was seen that all participants had no problem. As a result, it was found out that T1 and T2 have misconceptions in the subject area.

\section{Suggestions}

According to the results obtained in the subject matter knowledge we have seen that teachers have deficiencies and misconceptions on definition. In-service activities should be organized for teachers to be successful in teaching geometry. The content of the mathematics courses taken by prospective teachers at the university should also be reviewed in this context.

\section{References}

Aksu, Z. (2013). Sınıf Öğretmeni Adaylarının Kesirler Konusundaki Pedagojik Alan Bilgilerinin Gelişsimi. Yayımlanmamış yüksek lisans tezi, Atatürk Üniversitesi Eğitim Bilimleri Enstitüsü., Erzurum.

Alcock, L., \& Simpson, A. (2017). Interactions between defining, explaining and classifying: the case of increasing and decreasing sequences. Educ Stud Math, 94, 5-19. https://doi.org/10.1007/s10649-016-9709-4

Ball, D. L. (1988). Knowledge and reasoning in mathematical pedagogy: Examining what prospective teachers bring to teacher education (Unpublished doctoral dissertation b.). Eastt Lansing: Michigan State Univercity.

Dahlberg, R. P., \& Housman, D. L. (1997). Facilitating learning events through example generation. Educational Studies in Mathematics, 33(3), 283-299. https://doi.org/10.1023/A:1002999415887

De Villiers, M. (1998). To teach definitions in geometry or teach to define? (U. Stellenbosch.) Proceedings of the 22nd International Conference of the International Group for Psychology of Mathematics Education, 2, 248-255.

Dönmez, G. (2009). MateMatik öğretmen adaylarının limit ve süreklilik kavramlarına ilişkin pedagojik alan bilgilerinin değerlendirilmesi. İstanbul: Yayınlanmamış Yüksek Lisans Tezi, Marmara Üniversitesi Eğitim Bilimleri Enstitüsü, İstanbul

Edwards, B. S., \& Ward, M. B. (2004). Surprises from mathematics education research: Student (mis)use of mathematical definitions. $n s$. The American Mathematical Monthly, 111(5), 411-424.

Freudenthal, H. (1973). Mathematics as an educational task. Dordrecht: Reidel.

Gökbulut, Y., \& Ubuz, B. (2013). Sınıf Öğretmeni Adaylarının Prizma Bilgileri: Tanım ve Örnekler. İlköğretim Online, 12(2), 401-412.

Gökkurt, B. (2014). Ortaokul matematik ögretmenlerinin geometrik cisimler konusuna ilişkin pedagojik alan bilgilerinin incelenmesi. Yayımlanmamış Doktora tezi Atatürk Üniversitesi, Erzurum.

Hacioğlu, H., Haciyev, A., Kalantarov, V., \& Sabuncuoğlu, A. (2009). Matematik Terimleri Sözlüğ̈̈. İstanbul: Türk Dil Kurumu Yayınları.

Jaime, A., \& Gutiérrez, A. (1994). A model of test design to assess the van Hiele levels. Proceedings of the 18th International Conference of the International Group for Psychology of Mathematics Education, 3, 41-48. 
Mcmillian, H. J., \& Schumacher, S. (2010). Research in education. Boston USA: Pearson Education.

Özyıldırım-Gümüş, F., \& Şahiner, Y. (2017). Investigation on How Pre-service Elementary Mathematics Teachers Write and Use Mathematical Definitions. International Electronic Journal of Elementary Education, 9(3), 511-522.

Reed, S. K. (1972). Pattern recognition and categorization. Cognitive Psychology, 3(3), 382-407. https://doi.org/10.1016/0010-0285(72)90014-X

Şahin, Ö. (2016). İlköğretim matematik öğretmeni adaylarının cebir konusundaki pedagojik alan bilgilerinin gelişiminin incelenmesi yayımlanmamış Doktora tezi Atatürk Üniversitesi, Erzurum.

Shulman, L. S. (1986). Those who understand, Knowledge growth in teaching. Educational Researcher, 15(2), 4-14. https://doi.org/10.3102/0013189X015002004

TDK. (2009). Geometri (Atatürk). Ankara: Türk Dil Kurumu Yayınları.

Tsamir, P., Tirosh, D., \& Levenson, E. (2008). Intuitive nonexamples: the case of triangles. Educational Studies in Mathematics, 69(2), 81-95. https://doi.org/10.1007/s10649-008-9133-5

Türnüklü, E. (2014). Dörtgenlerde Aile İlişkilerinin Yapılandırılması: İlköğretim Matematik Öğretmen Adaylarının Ders Planlarının Analizi. Eğitim ve Bilim, 39(173), 197-204.

Unlu, M., \& Horzum, T. (2018). Mathematics Teacher Candidates' Definitions of Prism and Pyramid. International Journal of Research in Education and Science (IJRES), 4(2), 670-685. https://doi.org/10.21890/ijres.438373

van Hiele, P. M. (1986). Structure and insight. A theory of mathematics education. Orlando, Florida: Academic Press.

Yin, R. K. (2003). Case study research: design and methods (Robert K. Yin. 3rd ed, b.). United States of America: Applied social research methods series.

Zaslavsky, O., \& Shir, K. (2005). Students' conceptions of a mathematical definitions. Journal for Research in Mathematics Education, 36(4), 317-346.

Zazkis, R., \& Leikin, R. (2008). Exemplifying definitions: a case of a square. Educational Studies in Mathematics, 69(2), 131-148. https://doi.org/10.1007/s10649-008-9131-7

\section{Copyrights}

Copyright for this article is retained by the author(s), with first publication rights granted to the journal.

This is an open-access article distributed under the terms and conditions of the Creative Commons Attribution license (http://creativecommons.org/licenses/by/4.0/). 